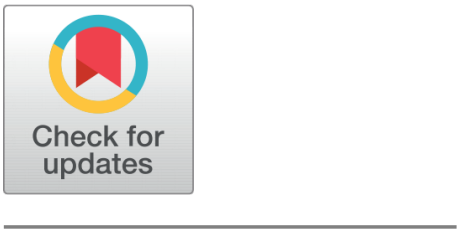

OPEN ACCESS

Received: $26-04-2020$

Accepted: 10-06-2020

Published: 06-07-2020

Editor: Dr. Natarajan Gajendran

Citation: Shami TK, Adil SA, Hassan S, Bashir MK (2020) Spatial market integration and price transmission in major potato markets of Punjab, Pakistan. Indian Journal of Science and Technology 13(23): 2328-2335. https://doi.org/ 10.17485/IJST/v13i23.411

* Corresponding author. Tanvir Khaliq Shami Institute of Agricultural and Resource Economics, University of Agriculture Faisalabad, 38040, Pakistan. Tel.: +92-300-666-7661 shami8080@gmail.com

Funding: None

Competing Interests: None

Copyright: @ 2020 Shami, Adil, Hassan, Bashir. This is an open access article distributed under the terms of the Creative Commons Attribution License, which permits unrestricted use, distribution, and reproduction in any medium, provided the original author and source are credited.

Published By Indian Society for Education and Environment (iSee)

\section{Spatial market integration and price transmission in major potato markets of Punjab, Pakistan}

\author{
Tanvir Khaliq Shami ${ }^{1}{ }^{*}$, Sultan Ali Adil ${ }^{1}$, Sarfraz Hassan ${ }^{1}$, \\ Muhammad Khalid Bashir ${ }^{1}$
}

1 Institute of Agricultural and Resource Economics, University of Agriculture Faisalabad, 38040, Pakistan. Tel.: +92-300-666-7661

\begin{abstract}
Application: These results suggest for market integration and competition rather than collusion in Potato markets in Punjab, Pakistan, and provide little justification for government intervention designed to improve competitiveness or to enhance market efficiency. Findings: The empirical results show as major Potato markets are integrated, i.e., there exist the law of one price. These findings also supported the results of the Granger causality analysis. The results of pairwise granger casualty show the direction of price transmission between the selected Potato markets in Punjab, Pakistan. Methods/Statistical analysis: The study estimated the data by using the Johansen Co-integration (J) technique, vector error correction model, and Vector autoregressive (VAR) model. Background/Objectives: This study investigated market integration and asymmetric price transmission in the potato markets for the seven major Potato markets, i.e., Okara, Faisalabad, Sargodha, Lahore, Gujranwala, Multan, and Rawalpindi in the province of Punjab, Pakistan.
\end{abstract}

Keywords: Market integration; Potato; Co-integration; Causality

\section{Introduction}

The concept of spatial market integration retained with the contribution of Jasdanwalla $^{(1)}$, Lele $^{(2)}$, and Jones ${ }^{(3)}$. The spatial market integration refers to the asymmetric price transmission in different markets, price signals are transmitted smoothly across the markets ${ }^{(4)}$. While if the markets are not integrated, price signals will not been transmitted through the marketing channels. Therefore, in the market-driven economies price signaling is an important tool to access market information through supply and demand particularly in case of agricultural commodity markets ${ }^{(5)}$. Price signaling coordinates the actions of economic agents and identifying the sources of market imperfection. Spatial market integration increased due to its potential application and assist producers and consumers to realize the gains from long-term comparative advantage. Spatial market integration also assists the government in agriculture price policy questions regarding government intervention in markets in the developing countries ${ }^{(6)}$. Spatial market integration information help governments for developing trade policy, 
subsequently for farmers that were trying to connect with larger international markets in the developing world ${ }^{(7,8)}$.

Price signaling provides an analytical tool to empirically investigate the hypothesis of spatial market integration. Jasdanwalla $^{(1)}$ and Lele ${ }^{(2)}$ estimated the spatial market integration through the correlation of coefficient, markets are said to be integrated if there exists a high correlation between prices of different markets. Later Dawson and Dey ${ }^{(9)}$, Ghosh ${ }^{(4)}$, Zahid, et al. ${ }^{(10)}$, and Choi, et al. ${ }^{(11)}$ criticized the correlation approach due to its static nature. They used the concept of co-integration technique to investigate the phenomena of market integration in the long run. When prices of different local markets are cointegrating these signals show the law of one price hold in the long run between the prices of given markets. More integrated markets yield lower price volatility ${ }^{(12,13)}$.

Potato is the most widely produced and consumed vegetable crop due to its nutrient capacity, potentials for diverse uses as well as easy availability to low-income consumers in the world ${ }^{(14)}$. There are more than 5000 potato varieties are available in the world; mostly belong to South America. Pakistan is in the 19th position in terms of production volume and contributes only 1.6 percent in total world production. Punjab contributes about 86 percent of the total production of potato in Pakistan ${ }^{(15)}$. Most of the literature emphasized on potato production in Pakistan, while relatively little was known about how price transmission mechanism takes place in potato vegetable markets. The following study empirically estimated the potato market integration through the co-integration and verified the existence of the law of one price in the selected markets (Okara, Faisalabad, Sargodha, Lahore, Gujranwala, Multan, and Rawalpindi, i.e., Okara, Faisalabad, Sargodha, Lahore, Gujranwala, Multan, and Rawalpindi of Punjab province ${ }^{(16)}$.

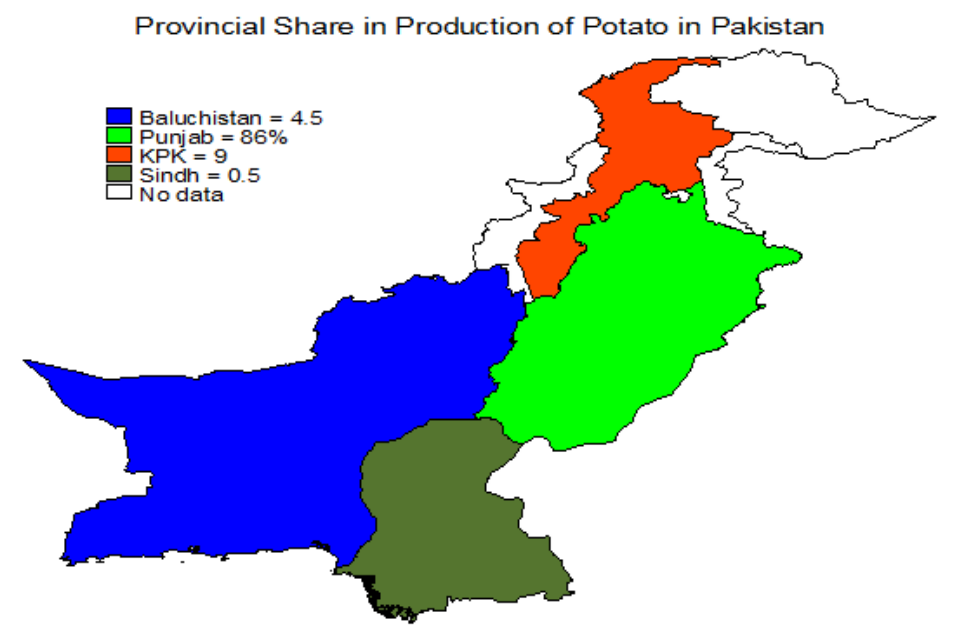

Fig 1. Provincial share of potato production in Pakistan

\section{Data and Methods}

To estimate the market integration through price transmission study uses the monthly wholesale price data January 2007 to November 2018 of potato for seven major markets Okara (Okara), Sargodha (SAR), Lahore (LHR), Faisalabad (FSD), Gujranwala (GUJ), Multan (MUL), and Rawalpindi (RWP)) of Punjab Province. Okara was set as a base market for the analysis and the data is taken from the Agricultural Market Information System (AMIS), Government of Punjab Pakistan ${ }^{(15)}$.

The study used the augmented Dickey-Fuller (ADF) test to test the stationarity problem of individual series used in the study, with and without a deterministic trend ${ }^{(17)}$. The Equation (1) explains the structure of the ADF equation without deterministic trend in case of Okara market:

$$
\Delta O \operatorname{kara}_{t}=\beta_{0}+\beta O \mathrm{kara}_{t-1}+\sum_{i=1}^{n} \alpha_{i} \Delta O \mathrm{kara}_{t-i}+\varepsilon_{t}
$$

ADF equation with a deterministic trend in case of Okara market:

$$
\Delta O \text { kara }_{t}=\beta_{0}+\beta_{1} O \text { karat }_{t-1}+\beta_{2} t+\sum_{i=1}^{n} \alpha_{i} \Delta O \operatorname{kara}_{t-i}+\varepsilon_{t}
$$

Market integration is the long-term phenomenon, markets said to be integrated if there exists co-integration in the long term. Johnson co-integration method presented by the Johansen ${ }^{(18)}$ and Johansen and Juselius ${ }^{(19)}$ one of the popular techniques to 
estimate the long-run co-integration among the markets. Johansen co-integration technique is based on the maximum likelihood (ML) procedure that is used to estimate the long-run relationship between the given markets. Johansen co-integration procedure are based on

- Trace statistics of the stochastic matrix

- Eigenvalue statistics of the stochastic matrix

Trace and These statistics are to determine the number of co-integrating equations. Johansen co-integration is based on the examination of $\pi$ matrix, $\pi$ interpret explain the long-run coefficient matrix. Where $\pi$ is the product of two matrices?

$$
\pi=\alpha \beta^{\prime}
$$

Where $\beta$ is the vectors of co-integrating equations, and $\alpha$ gives the amount of each co-integrating vector entering each equation of the VECM, also known as the 'adjustment parameter'.

$$
\begin{aligned}
& \lambda_{\text {Trace }}(r)=-T \sum_{i=r+1}^{g} i n\left(1-\widehat{\lambda}_{i}\right) \\
& \lambda_{\text {Max }}(r, r+1)=-T \ln \left(1-\widehat{\lambda}_{r+1}\right)
\end{aligned}
$$

Where $\widehat{\lambda}_{i}$ is the estimated value for the ith ordered eigenvalue from the $\pi$ matrix? In the Johansen co-integration technique, we first calculate the Trace and Maximum Eigenvalue statistics, then compare these to the critical values. In the case of cointegration Trace and Maximum Eigenvalue statistics greater than the critical values.

The long Run co-integration equation of the study

$$
\begin{aligned}
& \Delta \text { Okara }_{t}=\alpha+\sum_{i=1}^{m} \beta_{1 i} F_{S D} D_{t-i}+\sum_{i=1}^{m} \beta_{2 i} G U J_{t-i}+\sum_{i=1}^{m} \beta_{3 i} M_{U} L_{t-i}+\sum_{i=1}^{m} \beta S A R_{t-i}+\sum_{i=1}^{m} \beta_{5 i} L_{H} R_{t-i}+ \\
& \sum_{i=1}^{m} \beta_{6 i} R W P_{t-i}+\sum_{i=1}^{m} \beta \text { Okara }_{t-i}+\sum_{i=1}^{m} \beta_{8 i} \operatorname{VFSD}_{t-i}+\sum_{i=1}^{m} \beta_{9 i} \operatorname{VGUJ}_{t-i}+\sum_{i=1}^{m} \beta_{10 i} \mathrm{VMUL}_{t-i}+ \\
& \sum_{i=1}^{m} \beta_{11 i} \operatorname{VSAR}_{t-i}+\sum_{i=1}^{m} \beta_{12 i} \operatorname{VLHR}_{t-i}+\sum_{i=1}^{m} \beta_{13 i} \operatorname{VRWP}_{t-i}+\sum_{i=1}^{m} \beta_{14 i} \operatorname{VOkara}_{t-i}+\varepsilon_{t}
\end{aligned}
$$

Short Run co-integration Equation

$$
\begin{aligned}
& \Delta \text { Okara }_{t}=\sum_{i=1}^{m} \beta_{1 i} \mathrm{VFSD}_{t-i}+\sum_{i=1}^{m} \beta_{2 i} \mathrm{VGUJ}_{t-i}+\sum_{i=1}^{m} \beta_{3 i} \mathrm{VMUL} L_{t-i}+\sum_{i=1}^{m} \beta_{4 i} \mathrm{VSAR} R_{t-i}+\sum_{i=1}^{m} \beta_{5 i} \mathrm{VLHR} \\
& \sum_{i=1}^{m} \beta_{6 i} \mathrm{VRWP}_{t-i}+\sum_{i=1}^{m} \beta_{7 i} \mathrm{VOKara}_{t-i}+\beta_{8} \text { ECM }_{t-1}+\varepsilon_{t}
\end{aligned}
$$

Granger causality provides an important implication of co-integration. According to Granger ${ }^{(20)}$ if there exists co-integration between two variables, then there must exist the causality at least one direction. Subsequently, if two markets are integrated, the price in one market, P1, would commonly be found to Granger-cause the price in the other market, P2 and/or vice versa. Granger causality analysis generally performed by fitting a VAR model to the time series. In case of Okara market for with L lags as fellow:

$$
\operatorname{Okara}_{t}=\sum_{\lambda=1}^{L} A_{\lambda} \text { Okara }_{t-\lambda}+\varepsilon_{t}
$$

Where $\varepsilon_{t}$ is the white noise, and $A_{\lambda}$ is the matrix for every $\lambda$. The Sargodha market granger cause to another market, if at least one element of $A_{\lambda}(j, i)$ for $\lambda=1,2, \ldots, L$ significantly larger than zero.

Vector autoregressive (VAR) mechanism can also further be used to verify the dynamics of price transmission mechanism among selected potato markets. General structure of the vector autoregressive (VAR) model for Cotton Lint Production:

$$
\text { Okara }_{t}=\mu+A_{1} \mathrm{O} \mathrm{kara}_{t-1}+\ldots+A_{p} O \operatorname{kara}_{t-p}+\mu_{t}
$$

Where are the parameter matrices, and assume to be normally distributed with zero mean and constant variance.

$$
\text { Okara }_{t}=\mu+A_{1} O \operatorname{kara}_{t-1}+\ldots+A_{p \max } O \text { kara }_{t-p \max }+\mu
$$

The VAR with only lags

$$
p \leq p_{\operatorname{Max}}
$$




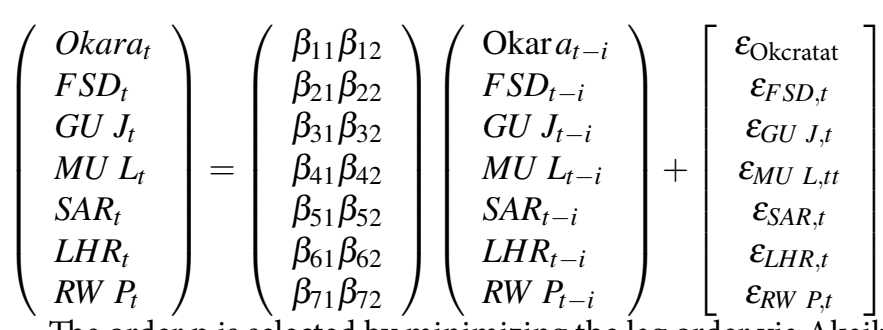

The order $\mathrm{p}$ is selected by minimizing the lag order via Akaike information criterion (AIC)

$$
A I C(m)=\ln \left|\sum_{\mu}(m)\right|+\frac{2}{T} m K^{2}
$$

And

$$
B I C(m)=\ln \left|\sum_{\mu}(m)\right|+\frac{\ln T}{T} m K^{2}
$$

\section{Results and Discussion}

The concept of market integration was introduced by Jasdanwalla ${ }^{(1)}$, Farrukh ${ }^{(21)}$, Jones ${ }^{(3)}$, Lele ${ }^{(2)}$, and Blyn ${ }^{(22)}$. They used the concept of correlation to investigate market integration. The value of the correlation coefficient range -1 to $1,-1$ mean perfect negative correlation and +1 mean perfect positive correlation. The higher correlation between the market prices shows the higher association between markets and lower correlation shows lower market integration. Table 1 depicted the empirical results of strong positive correlation between the seven major potato markets prices. The value of the correlation coefficient value shows there exist 97, 96, 95, 95, 97 and 96 percent correlation of Okara market prices with, Faisalabad, Lahore, Rawalpindi, Sargodha, Multan and Gujranwala markets respectively.

Table 1. Correlation Matrix

\begin{tabular}{llllllll}
\hline Markets & OKARA & FSD & LHR & RWP & SAR & MUL & GUJ \\
\hline Okara & 1.00 & & & & & & \\
FSD & 0.97 & 1.00 & & & & & \\
LHR & 0.96 & 0.98 & 1.00 & & & & \\
RWP & 0.95 & 0.96 & 0.97 & 1.00 & & & \\
SAR & 0.95 & 0.97 & 0.95 & 0.93 & 1.00 & & \\
MUL & 0.97 & 0.97 & 0.96 & 0.95 & 0.97 & 1.00 & \\
GUJ & 0.96 & 0.98 & 0.98 & 0.97 & 0.96 & 0.97 & 1.00 \\
\hline
\end{tabular}

Source: Author self-estimation, using EViews 10

Harriss ${ }^{(23)}$ many others criticized the correlation approach to estimate the market integration due to its static nature and high correlation coefficients show the situation of physical discontinuities in the markets. Jones ${ }^{(24)}$ investigated the low correlation coefficient in sorghum prices between two Nigerian towns closely linked to the high cost of transport. They introduced the concept of co-integration, markets are said to be integrated if there exist co-integration and price shock in one market reflected in the other markets' prices ${ }^{(25)}$.

Before estimating the co-integration, it is a prerequisite to investigate the order of stationarity of the time-series data. The examined the stationarity order, using the Augmented Dickey-Fuller test (ADF) with drift only and with drift and trend. Table 2 depicted the unit root results of the Augmented Dickey-Fuller test (ADF) at the level and first difference. The estimated results of Table 2 indicate we fail to reject the null hypothesis of the ADF test at level with and without trend and do not reject the null hypothesis of the ADF test at the first difference with and without trend for all price series. So, it is concluded, all price series are non-stationary at the level and stationary at the first difference with and without a trend.

The estimated results of the ADF unit root test shows all the series are integrated order one. So, we can apply the Johnson cointegration technique to estimate the market integration through the long-run relationship between the price series of selected markets of Punjab. Before estimating the long-run relationship, it is preconditioned to select the lag length, using a vector autoregressive (VAR) model. Table 3 depicted the empirical results of the AR Lag Selection Criteria. The study selects the lag order two based on the Akaike information criterion (AIC). 
Table 2. ADF Unit Root Test Results

\begin{tabular}{|c|c|c|c|c|c|c|c|c|}
\hline \multirow{2}{*}{ Variables } & \multicolumn{2}{|c|}{ Log Level Form } & \multicolumn{2}{|c|}{ Log Level Form } & \multicolumn{4}{|c|}{ First Difference Form } \\
\hline & $\begin{array}{l}\text { Without } \\
\text { Trend }\end{array}$ & Pro & With Trend & Pro & $\begin{array}{l}\text { Without } \\
\text { Trend }\end{array}$ & Pro & With Trend & Pro \\
\hline Okara & -2.89 & 0.05 & -2.82 & 0.19 & -10.00 & 0.00 & -10.09 & 0.00 \\
\hline SAR & -6.70 & 0.00 & -7.58 & 0.00 & -10.00 & 0.00 & -10.09 & 0.00 \\
\hline LHR & -2.68 & 0.08 & -2.85 & 0.18 & -2.90 & 0.05 & -3.90 & 0.01 \\
\hline FSD & -2.55 & 0.11 & -2.41 & 0.38 & -3.70 & 0.01 & -3.84 & 0.02 \\
\hline RWP & -3.45 & 0.07 & -3.36 & 0.06 & -5.00 & 0.00 & -5.45 & 0.00 \\
\hline MUL & -2.72 & 0.07 & -2.53 & 0.31 & -2.98 & 0.04 & -3.14 & 0.02 \\
\hline GUJ & -3.02 & 0.04 & -2.80 & 0.20 & -11.26 & 0.00 & -11.32 & 0.00 \\
\hline
\end{tabular}

Source: Author self-estimation, using EViews 10.

Table 3. VAR Lag Order Selection Criteria

\begin{tabular}{llllll}
\hline Lag & LR & FPE & AIC & SC & HQ \\
\hline 0 & NA & $1.42 \mathrm{E}-12$ & -7.41544 & -7.262564 & -7.353318 \\
1 & 416.7865 & $1.04 \mathrm{E}-13$ & -10.0342 & $-8.811190^{*}$ & $-9.537223^{*}$ \\
2 & 105.3884 & $8.89 \mathrm{e}-14^{*}$ & $-10.19253^{*}$ & -7.89939 & -9.260702 \\
3 & 56.83355 & $1.13 \mathrm{E}-13$ & -9.966773 & -6.603504 & -8.600095 \\
4 & 63.11216 & $1.33 \mathrm{E}-13$ & -9.837088 & -5.403688 & -8.035558 \\
5 & 65.36344 & $1.48 \mathrm{E}-13$ & -9.775533 & -4.272002 & -7.53915 \\
6 & 66.0448 & $1.59 \mathrm{E}-13$ & -9.775185 & -3.201523 & -7.10395 \\
7 & $80.01884^{*}$ & $1.40 \mathrm{E}-13$ & -10.0086 & -2.364807 & -6.902514 \\
8 & 33.58276 & $2.18 \mathrm{E}-13$ & -9.713946 & -1.000022 & -6.173007 \\
\hline
\end{tabular}

* indicates lag order selected by the criterion

LR: sequentially modified LR test statistic (each test at 5\% level); FPE: Final prediction error; AIC: Akaike information criterion; SC: Schwarz information criterion; HQ: Hannan-Quinn information criterion

Table 4 represented the estimated results of the Johnson cointegration test based on Trace and Max-eigenvalue test statistics. The empirical results of Table 4 show that Trace and Max-eigenvalue are greater than the critical values at $r \leq 5$ and subsequently probability values also indicate long run co-integrating in six markets at 5 percent level of significance and one market cointegrating in the prices of selected Potato markets in Punjab at 10 percent level of significance. In other words, estimated results suggested, six out of seven markets in Punjab are fully integrated and confirm the existence of the law of one price (LOP) following Mushtaq, et al. ${ }^{(26)}$, Ghafoor, et al. ${ }^{(27)}$ and Verkaart, et al. ${ }^{(28)}$.

Table 5 illustrates the Johnson co-integration test empirical results of selected potato markets in Punjab. The pairwise cointegration results are estimated by taking Okara as a base market. The prices of selected markets Faisalabad, Lahore, Gujranwala, Multan, Sargodha, and Rawalpindi are co-integrated with Okara market prices in Punjab. Table 6 presented the empirical results of Johnson pair-wise co-integration long-run elasticities of all selected markets with Okara market. The empirical results of table 6 show that a one percent increase in the price of potato in the Okara market increases the $0.76,0.73,0.730 .98$, and 3.34 percent in Faisalabad, Gujranwala, Lahore, Rawalpindi, and Sargodha markets respectively in long run.

Table 7 represented the Johnson pair wise short-run speed of adjustment of each market withOkara market. The empirical results of the pairwise short-run speed of adjustment of each market with Okara market show that $80,69,77,21,86$ and 8 percent convergence take place in Faisalabad, Lahore, Gujranwala, Multan, Rawalpindi, and Sargodha markets in one month, this implies that economic agents take back to long-run equilibrium within two months.

The study used the Granger causality to investigate the law of one price (LOP) and provide implication of co-integration among the selected potato markets of Punjab. Because if there exist co-integration between the prices of two markets, then there must exist the causality at least one direction. Granger causality examines the direction of price transmission between the markets. Table 8 presented the estimated results of the pairwise Granger causality test. The estimated results show in the case of Faisalabad, Multan, and Sargodha there exists unidirectional granger causality at a 5 percent level of significance. Okara market potato prices granger causes the Faisalabad, Multan, and Sargodha markets prices, while potato prices of Faisalabad, Multan, 
Table 4. Johnson co-integration test Results

\begin{tabular}{|c|c|c|c|c|}
\hline \multicolumn{5}{|c|}{ Co-integration Rank Test (Trace) } \\
\hline Hypothesized & & Trace & 0.05 & \multirow[b]{2}{*}{ Prob.** } \\
\hline No. of CE(s) & Eigenvalue & Statistic & Critical Value & \\
\hline $\mathrm{r}=0^{\star}$ & 0.41 & 288.45 & 125.62 & 0.00 \\
\hline$r \leq 1^{*}$ & 0.35 & 214.49 & 95.75 & 0.00 \\
\hline$r \leq 2^{*}$ & 0.32 & 154.32 & 69.82 & 0.00 \\
\hline$r \leq 3^{*}$ & 0.25 & 101.21 & 47.86 & 0.00 \\
\hline$r \leq 4^{*}$ & 0.19 & 62.11 & 29.80 & 0.00 \\
\hline$r \leq 5^{*}$ & 0.16 & 32.88 & 15.49 & 0.00 \\
\hline$r \leq 6$ & 0.06 & 8.82 & 3.84 & 0.00 \\
\hline \multicolumn{5}{|c|}{ Co-integration Rank Test (Maximum Eigenvalue)) } \\
\hline Hypothesized & & Max-eigenvalue & 0.05 & \multirow[b]{2}{*}{ Prob. ${ }^{* *}$} \\
\hline No. of CE(s) & Eigenvalue & Statistic & Critical Value & \\
\hline $\mathrm{r}=0^{*}$ & 0.41 & 73.96 & 46.23 & 0.00 \\
\hline$r \leq 1^{*}$ & 0.35 & 60.18 & 40.08 & 0.00 \\
\hline$r \leq 2^{*}$ & 0.32 & 53.10 & 33.88 & 0.00 \\
\hline$r \leq 3^{*}$ & 0.25 & 39.10 & 27.58 & 0.00 \\
\hline$r \leq 4^{*}$ & 0.19 & 29.23 & 21.13 & 0.00 \\
\hline$r \leq 5^{*}$ & 0.16 & 24.06 & 14.26 & 0.00 \\
\hline$r \leq 6$ & 0.06 & 8.82 & 3.84 & 0.00 \\
\hline
\end{tabular}

Trace and Max-eigenvalue test indicates 6 co-integrating eqn(s) at the 0.05 level

* denotes rejection of the hypothesis at the 0.05 level

The alternative hypothesis of trace statistics $\mathrm{r}=\mathrm{k}$, while Alternative hypothesis of Maxeigenvalue statistics $r=r^{*}+1$

${ }^{* *}$ MacKinnon-Haug-Michelis (1999) p-values

Table 5. Johnson pair-wise Co-integration test Results

\begin{tabular}{|c|c|c|c|c|c|c|c|}
\hline \multirow{2}{*}{$\begin{array}{l}\text { Markets } \\
\text { Pair }\end{array}$} & \multicolumn{2}{|l|}{ Hypothesized } & \multirow{2}{*}{$\begin{array}{l}\text { Trace } \\
\text { Critical } \\
\text { Value }\end{array}$} & \multirow{2}{*}{$\begin{array}{l}0.05 \\
\text { Prob. }\end{array}$} & \multirow{2}{*}{$\begin{array}{l}\text { Hypothesized } \\
\text { Max-Eigen } \\
\text { Statistic }\end{array}$} & \multirow{2}{*}{$\begin{array}{l}\text { Max-Eigen } \\
\text { Critical Value }\end{array}$} & \multirow{2}{*}{$\begin{array}{l}0.05 \\
\text { Prob. }\end{array}$} \\
\hline & No. of CE(s) & $\begin{array}{l}\text { Trace Statis- } \\
\text { tic }\end{array}$ & & & & & \\
\hline \multirow{2}{*}{ Okara_MUL } & $\mathrm{r}=0^{*}$ & 59.88 & 15.49 & 0.00 & 37.26 & 14.26 & 0.00 \\
\hline & $\mathrm{r} \leq 1^{*}$ & 22.62 & 3.84 & 0.00 & 22.62 & 3.84 & 0.00 \\
\hline \multirow{2}{*}{ Okara_FSD } & $\mathrm{r}=0^{*}$ & 67.35 & 15.49 & 0.00 & 36.77 & 14.26 & 0.00 \\
\hline & $\mathrm{r} \leq 1^{*}$ & 30.58 & 3.84 & 0.00 & 30.58 & 3.84 & 0.00 \\
\hline \multirow{2}{*}{ Okara_LHR } & $\mathrm{r}=0^{\star}$ & 51.42 & 15.49 & 0.00 & 41.48 & 14.26 & 0.00 \\
\hline & $r \leq 1^{*}$ & 9.94 & 3.84 & 0.00 & 9.94 & 3.84 & 0.00 \\
\hline \multirow{2}{*}{ Okara_GUJ } & $\mathrm{r}=0^{*}$ & 51.60 & 15.49 & 0.00 & 40.08 & 14.26 & 0.00 \\
\hline & $\mathrm{r} \leq 1^{\star}$ & 11.51 & 3.84 & 0.00 & 11.51 & 3.84 & 0.00 \\
\hline \multirow{2}{*}{ Okara_SAR } & $\mathrm{r}=0^{*}$ & 64.59 & 15.49 & 0.00 & 39.39 & 14.26 & 0.00 \\
\hline & $\mathrm{r} \leq 1^{*}$ & 25.20 & 3.84 & 0.00 & 25.20 & 3.84 & 0.00 \\
\hline \multirow{2}{*}{ Okara_RWP } & $\mathrm{r}=0^{*}$ & 62.45 & 15.49 & 0.00 & 48.91 & 14.26 & 0.00 \\
\hline & $\mathrm{r} \leq 1^{*}$ & 13.54 & 3.84 & 0.00 & 13.54 & 3.84 & 0.00 \\
\hline
\end{tabular}

* denotes rejection of the hypothesis at the 0.05 level

The alternative hypothesis of trace statistics $r=k$, while Alternative hypothesis of Max-eigenvalue statistics $r=r^{*}+1$

${ }^{* *}$ MacKinnon-Haug-Michelis(1999) p-values 
Table 6. Pair wise long-run elasticities

\begin{tabular}{lllllll}
\hline Relationship of Okara with other markets & FSD & GUJ & LHR & MUL & RWP & SAR \\
\hline Coefficient & 0.76 & 0.82 & 0.73 & -0.29 & 0.98 & 3.34 \\
Stander error & 0.06 & 0.07 & 0.07 & 0.22 & 0.06 & 0.34 \\
T-Statistics & 13.32 & 12.39 & 10.28 & -1.36 & 15.18 & 9.76 \\
\hline
\end{tabular}

Table 7. Pairwise speed of adjustment

\begin{tabular}{llll}
\hline Relationship with Okara & Coefficient & $\begin{array}{l}\text { T- } \\
\text { value }\end{array}$ & P-value \\
\hline FSD & -0.80 & -6.33 & 0.00 \\
LHR & -0.69 & -6.63 & 0.00 \\
GUJ & -0.77 & -6.63 & 0.00 \\
MUL & -0.21 & -5.90 & 0.00 \\
RWP & -0.86 & -7.24 & 0.00 \\
SAR & 0.08 & 3.75 & 0.00 \\
\hline
\end{tabular}

and Sargodha markets are not granger causes the Okara markets prices. In the case of Lahore, Gujranwala and Rawalpindi there exist bidirectional causality.

Table 8. Results of the pairwise granger causality test

\begin{tabular}{llll}
\hline Pairwise Granger Causality & F-statistics & P-value & Direction \\
\hline Okara $\rightarrow$ FSD & 9.57 & 0.00 & Uni- \\
FSD $\rightarrow$ Okara & 1.42 & 0.24 & Directional \\
Okara $\rightarrow$ LHR & 7.52 & 0.00 & Bi- \\
LHR $\rightarrow$ Okara & 6.52 & 0.00 & Directional \\
Okara $\rightarrow$ MUL & 5.28 & 0.00 & Uni- \\
MUL $\rightarrow$ Okara & 0.53 & 0.66 & Direction \\
Okara $\rightarrow$ GUJ & 8.98 & 0.00 & Bi- \\
GUJ $\rightarrow$ Okara & 3.79 & 0.01 & Directional \\
Okara $\rightarrow$ SAR & 15.80 & 0.00 & Uni- \\
SAR $\rightarrow$ Okara & 1.62 & 0.19 & Directional \\
Okara $\rightarrow$ RWP & 7.43 & 0.00 & Bi- \\
RWP $\rightarrow$ Okara & 4.98 & 0.00 & Direction \\
\hline
\end{tabular}

\section{Summary and Conclusion}

The paper investigated the hypothesis of market integration in the selected major potato markets in Punjab using the correlation matrix method and Johnson co-integration analysis. To estimate the phenomena of integration in the potato markets prices study used the monthly wholesale price data from January 2007 to November 2018. The estimated results of the study show that there exists a strong positive correlation between the seven selected potato markets (Okara, Faisalabad, Lahore, Multan, Gujranwala, Sargodha, and Rawalpindi) in Punjab. The empirical result of the Johnson co-integration test also confirms the existence of the law of one price in the six major potato markets out of seven potato markets in Punjab.

The pairwise elasticities also confirmed market price linkages are important in economic analysis through the speed of adjustment in the long run. The estimated results show a one percent increase in the price of potato in the Okara market increases the 0.76, 0.82, 0.73, 0.98, and 3.34 percent in Faisalabad, Gujranwala, Lahore, Rawalpindi, and Sargodha markets respectively in long run. The results of pairwise granger casualty show the direction of price transmission between the selected Potato markets in Punjab. The empirical results of the study reported the high degree of market integration in major Potato markets and are consistent with the view that Potato markets in Pakistan are quite competitive and provide little justification for government intervention designed to improve competitiveness or to enhance market efficiency. 


\section{References}

1) Jasdanwalla Z . 1966,. Available from: https://bit.ly/2VxaxW7.

2) Lele UJ. Food grain marketing in India. Private performance and public policy. Ithaca, NY/London. Cornell University Press . 1971,. Available from: https://bit.ly/3cjAuPV.

3) Jones D. Marketing staple food crops in tropical Africa-jones, wo. Canadian assn afr stud carleton univ, Dept geography, Ottawa on k1s 5b6. Canada. 1973;.

4) Ghosh M. Spatial integration of wheat markets in India: Evidence from cointegration tests. Oxford Development Studies. 2003;31(2):159-171.

5) Kohls RL and Uhl JN. Prentice-Hall Inc . 2002,. Available from: https://bit.ly/2REAlyI.

6) Alexander C and Wyeth J. Cointegration and market integration: An application to the Indonesian rice market. Journal of Development Studies. 1994;30(2):303-334. Available from: https://dx.doi.org/10.1080/00220389408422317.

7) Naseer M, Mehdi M, Ashfaq M, Hassan S and Abid M. Effect of marketing channel choice on the profitability of citrus farmers: Evidence form PunjabPakistan. Pakistan Journal of Agricultural Sciences. 2019;56(4):1003-1011.

8) ur Rehman Naseer MA, Ashfaq M, Hassan S, Adil SA and Ariyawardana A. Outlook on the global trade competitiveness of Pakistan's mandarin industry: An application of revealed symmetric comparative advantage framework. Outlook on Agriculture. 2019;48(1):66-74. Available from: https://dx.doi.org/ 10.1177/0030727018817788.

9) Dawson PJ and Dey PK. Testing for the law of one price: rice market integration in Bangladesh. Journal of International Development. 2002;14(4):473-484. Available from: https://dx.doi.org/10.1002/jid.888. doi:10.1002/jid.888.

10) Zahid MS, Qayyum A and Malik WS. Dynamics of Wheat Market Integration in Northern Punjab, Pakistan. The Pakistan Development Review. 2007;46:817-830. Available from: https://dx.doi.org/10.30541/v46i4iipp.817-830.

11) Choi M, Yun L and Kalas D. Pulses market performance in Myanmar. Indian journal of Agricultural economics. 2008;43(7):429-442.

12) Ravallion M . 1996,. Available from: https://bit.ly/2xpFsMl.

13) Ravallion M. Testing Market Integration. American Journal of Agricultural Economics. 1986;68(1):102-109. Available from: https://dx.doi.org/10.2307/ 1241654.

14) Anwar D, Shabbir D, Shahid MH and Samreen W. Determinants of potato prices and its forecasting: A case study of. Punjab, Pakistan; Munich, Germany .2015,. Available from: https://bit.ly/34FKjov.

15) Agricultural Marketing Information System, Government of Punjab. GOP. 2019;.

16) GOP Agriculture Census 2010 - Pakistan Report. 2012;.

17) Dickey DA and Fuller WA. Likelihood Ratio Statistics for Autoregressive Time Series with a Unit Root. Econometrica. 1981;49(4):1057-1057. Available from: https://dx.doi.org/10.2307/1912517.

18) Johansen S. Statistical analysis of cointegration vectors. Journal of economic dynamics and control. 1988;12(3):90041-90044.

19) Johansen $S$ and Juselius K. Maximum likelihood estimation and inference on cointegration-with applications to the demand for money. Oxford Bulletin of Economics and statistics. 1990;52(2):169-210.

20) Granger CW. Some recent development in a concept of causality. Journal of econometrics. 1988;39(1):199-211.

21) Farrukh MO. The structure and performance of the rice marketing system in E. Pakistan. The structure and performance of the rice marketing system in E. Pakistan. 1970;31.

22) Blyn G. Price series correlation as a measure of market integration. Indian Journal of Agricultural Economics. 1973;28(2):56-59.

23) Harriss B . 1979,.

24) Jones WO. Some Economic Dimensions of Agricultural Marketing Research. Regional Analysis, 1st Edn. 1976;p. 303-326.

25) Goodwin BK and Schroeder TC. Cointegration Tests and Spatial Price Linkages in Regional Cattle Markets. American Journal of Agricultural Economics. 1991;73(2):452-464. Available from: https://dx.doi.org/10.2307/1242730. doi:10.2307/1242730.

26) Mushtaq K, Gafoor AGA and Dad MDM. Apple Market Integration: Implications for SustainableAgricultural Development. THE LAHORE JOURNAL OF ECONOMICS. 2008;13:129-138. Available from: https://dx.doi.org/10.35536/lje.2008.v13.i1.a5.

27) Ghafoor A, Mustafa K, Mushtaq K and Abedullah A. Cointegration and Causality: An Application to Major MangoMarkets in Pakistan. THE LAHORE JOURNAL OF ECONOMICS. 2009;14(1):85-113. Available from: https://dx.doi.org/10.35536/lje.2009.v14.i1.a4.

28) Verkaart S, Munyua BG, Mausch K and Michler JD. Welfare impacts of improved chickpea adoption: A pathway for rural development in Ethiopia? Food Policy. 2017;66:50-61. Available from: https://dx.doi.org/10.1016/j.foodpol.2016.11.007. 